\title{
PREISACH MODEL USED TO DECRIBE RESPONSE OF CLAY IN DIRECT SHEAR TEST
}

\author{
Dragoslav Šumarac ${ }^{1}$ \\ Nikola Božović ${ }^{2}$ \\ Marija Krstić ${ }^{3}$ \\ Stefan Mitrović ${ }^{4}$
}

UDK: 691.261:620.21:517.957

DOI: $10.14415 /$ konferencijaGFS2021.26

Summary: Mathematical modeling of engineering materials is important issue in design of structures. Model itself should satisfy two conditions: first to explain in the best way mechanical behavior of material and second to be as simple as possible for easy everyday application in engineering. In the present paper the Preisach model is applied to behaviour of clay as an elasto-plastic material under direct shear test. The clay sample was taken by exploratory drilling on the territory of Šimanovci from a depth of $9.1 \mathrm{~m}$ to $9.3 \mathrm{~m}$. First, an experimental examination of a clay sample was performed in order to classify and determine the resistance-deformable characteristics. The clay is classified as CH-clay of high plasticity. The sample was then subjected to direct shear test. All obtained results clearly show advantages of the Preisach model for describing behavior of elastoplastic material. This analytical model allows an accurate computation of all points on the result curve from the direct shear test.

Keywords: Preisach model, clay, directshear test

\section{INTRODUCTION}

Preisach model originally is used for defining hysteretic phenomenon in magnetism [1], the model quickly found application in other fields of physics. The first implementation of this model in continuum mechanics describes the behavior of ductile materials under cyclic loading $[2,3]$. Later on model was applied for elastoplastic cyclic bending of beams

\footnotetext{
${ }^{1}$ Prof. dr Dragoslav Šumarac, dipl. inž. građ., redovni profesor na Građevinskom fakultetu Univerziteta u Beogradu, e-mail: dragosumi@gmail.com

${ }^{2}$ Nikola Božović, mast.inž.građ., student doktorskih studija, Institut za ispitivanje materijala-IMS, Beograd, email:nikola.bozovic@institutims.rs

${ }^{3}$ Marija Krstić, mast.inž.građ., student doktorskih studija, Institut za ispitivanje materijala-IMS, Beograd, email:marija.krstic@institutims.rs

${ }^{4}$ Stefan Mitrović, mast.inž.građ., student doktorskih studija, Institut za vodoprivredu Jaroslav Černi, Beograd, e-mail:stefan.mitrovic@jcerni.rs
} 
Савремена достигнућа у грађевинарству 22-23. април 2021. Суботица, СРБИЈА

[7, 8]. Generally, the Preisach model is hysteretic operator used for defining cyclic behavior of ductile materials.

In addition to the primary characteristic of a model to describe the cyclic behavior of materials, it has capability to accurately describe the monotonic behavior of the material. Existing models, mapping strain $\varepsilon(t)$ as input into stress $\sigma(t)$ as output, are based on bilinear working diagrams (Fig. 2). They are used for modeling cyclic and monotonic behavior of ideally elasto-plastic materials and ideally elasto-plastic materials with linear hardening. In this paper we used this model to describe behavior of clay in direct shear test.

\section{THE PREISACH MODEL OF HYSTERESIS}

According to Mayergoyz [6], the Preisach model implies the mapping of an input $u(t)$ to the output $f(t)$ in the integral form:

$$
f(t)=\iint P(\alpha, \beta) G_{\alpha, \beta} u(t) d \alpha d \beta,
$$

where $G_{\alpha, \beta}$ is an elementary hysteresis operator given in Figure 1 (a). Parameters $\alpha$ and $\beta$ are up and down switching values of the input, while $P(\alpha, \beta)$ is the Preisach function. i.e. a weight (Green's) function of the hysteresis nonlinearity to be represented by the Preisach model. The domain of integration of integral (1) is right triangle in the $\alpha, \beta$ plane, with $\alpha=\beta$ being the hypotenuse and $\left(\alpha_{0}, \beta_{0}=-\alpha_{0}\right)$ being the triangular vertex Figure 1.(b). History of loading corresponds to staircase line $L(t)$ which divides triangle into two parts (Lubarda et al.[2]). Maxima or minima of loading history are represented by the vertices with coordinates $(\alpha, \beta)$ on staircase line $L(t)$ in such a way if the input at a previous instant of time is increased, the final link of $L(t)$ is horizontal, and vice versa, if it is decreased it is vertical. Therefore, the triangle is divided into two parts with the positive and negative values of $G_{\alpha, \beta}$ by the interface staircase line $L(t)$.

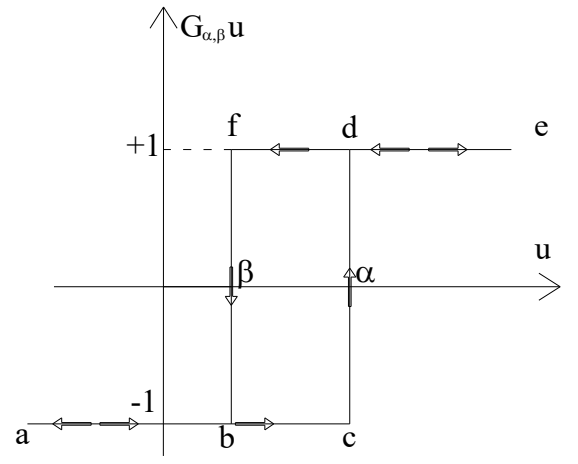

(a)

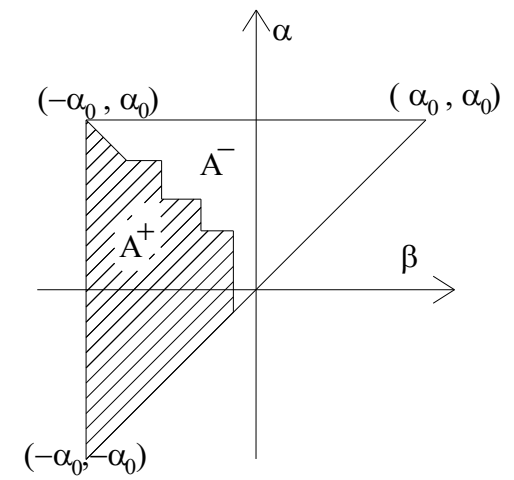

(b)

Figure 1. (a) Elementary hysteresis operator (b) Limiting triangle with the interface staircase line $L(t)$ 
Contemporary achievements in civil engineering 22-23. April 2021. Subotica, SERBIA

From formula (1) it is obtained:

$$
f(t)=\iint_{A^{*}(t)} P(\alpha, \beta) G_{\alpha, \beta} u(t) d \alpha d \beta-\iint_{A^{-}(t)} P(\alpha, \beta) G_{\alpha, \beta} u(t) d \alpha d \beta
$$

Denoting the output value at $u=\beta$ by $f_{\alpha, \beta}$ from the limiting triangle, it follows that:

$$
f_{\alpha, \beta}-f_{\alpha}=-2 \int_{\beta}^{\alpha}\left(\int_{\beta^{\prime}}^{\alpha} P\left(\alpha^{\prime}, \beta^{\prime}\right) d \alpha^{\prime}\right) d \beta^{\prime}
$$

By differentiating expression (3) twice, with respect to $\alpha$ and $\beta$, the Preisach weight function is derived in the form:

$$
P(\alpha, \beta)=\frac{1}{2} \frac{\partial^{2} f_{\alpha, \beta}}{\partial \alpha \partial \beta}
$$

The Preisach model explained above possesses two properties: wiping out and congruency properties. Those properties and much more about Preisach model is explained in the Lubarda et al. [2] and [3].

\section{THE PREISACH MODEL FOR CYCLIC BEHAVIOR OF DUCTILE MATERIALS}

One dimensional hysteretic behavior of elasto-plastic material can be successfully described by the Preisach model. Ductile material is represented in various ways by a series or parallel connections of elastic (spring) and plastic (slip) elements, explained in Lubarda, at al. [2].

Elastic-linearly hardening material behavior, characterized by the stress-strain curve shown in Figure 2a. ( $E$ and $E_{h}$ are elastic and hardening modules respectively), can be modeled by a three-element unit shown in Figure $2 \mathrm{~b}$. Elastic element of length $l_{0}$ and modules $E_{0}$ is connected in a series with a parallel connection of elastic and slip element, of length $L_{0}$ modulus $h_{0}$ and yield strength $Y$. It then follows that $E=E_{0}\left(l_{0}+L_{0}\right) / l_{0}$ and $E_{h}$ $=E h(E+h)$, where $h=h_{0}\left(l_{0}+L_{0}\right) / L_{0}$. 
8.

Савремена достигнућа у грађевинарству 22-23. април 2021. Суботица, СРБИЈА

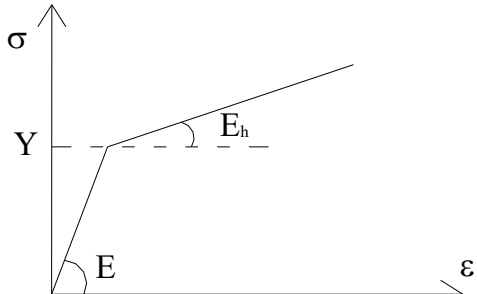

(a)

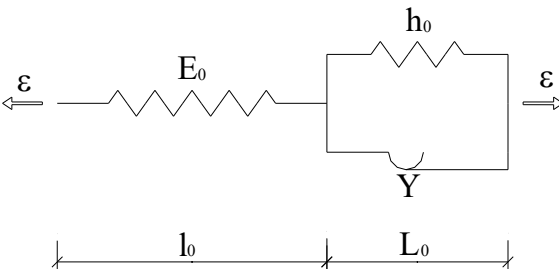

(b)

Figure 2.(a) Elastic-linearly hardening stress-strain behavior with elastic modulus E, initial yield stress $Y$ and hardening modulus $E_{h}$. (b) Three-element unit reproducing the stress-strain behavior in (a)

\section{A THREE-ELEMENT UNIT CONNECTED IN PARALLEL}

In this case the Preisach function can be determined from the hysteresis nonlinearity shown in Figure 2a again, taking into consideration that strain is input and stress is output. The Preisach function in this case has support along the lines $\alpha-\beta=0$ and $\alpha-\beta=2 Y / E$, i.e.it is given by:

$$
P(\alpha, \beta)=\frac{E}{2}\left[\delta(\alpha-\beta)+\frac{E-E_{h}}{2} \delta(\alpha-\beta-2 Y / E)\right]
$$

The expression for stress as a function of applied strain is, consequently:

$$
\sigma(t)=\frac{E}{2}\left[\int_{-\varepsilon_{0}}^{\varepsilon_{0}} G_{\alpha, \alpha} \varepsilon(t) d \alpha-\frac{\left(E-E_{h}\right)}{E} \int_{2 Y / E-\varepsilon_{0}}^{\varepsilon_{0}} G_{\alpha, \alpha-2 Y / E} \varepsilon(t) d \alpha\right]
$$

The first and second term on the right-hand side of (6) are elastic and plastic stress, respectively. For a system consisting of infinitely many of three-element units, connected in a parallel and with uniform yield strength distribution within the range $Y_{\min } \leq Y \leq Y_{\max }$, the total stress is:

$$
\sigma(t)=\frac{E}{2}\left[\int_{-\varepsilon_{0}}^{\varepsilon_{0}} G_{\alpha, \alpha} \varepsilon(t) d \alpha-\frac{E-E_{h}}{2} \frac{1}{Y_{\max }-Y_{\min }} \iint_{A} G_{\alpha, \beta} \varepsilon(t) d \alpha d \beta\right]
$$

In (7) the integration domain $A$ is the area of the band contained between the lines $\alpha-\beta=2 Y_{\min } / E$ and $\alpha-\beta=2 Y_{\max } / E$ in the limiting triangle, shown in Figure 3 (b). 


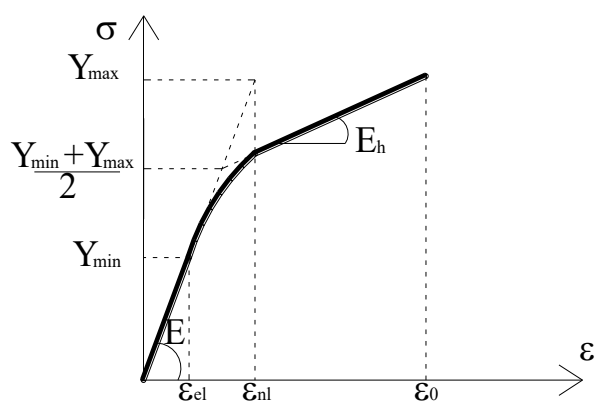

(a)

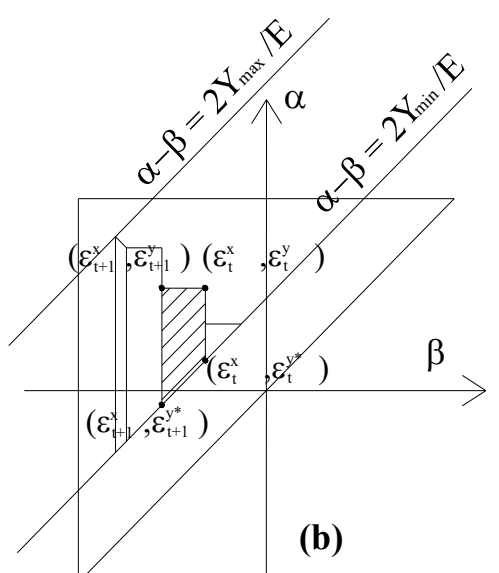

(b)

Figure 3. (a) Parametars for Preisch model from real curve (b) Preisach triangle with limits for plastic area

\section{RESULTS OF EXPERIMENTAL TESTS OF CLAY}

In this paper, the application of Preisach model for describing the behavior of clay in the direct shear test will be presented. The clay sample was obtained by exploratory drilling on the territory of the municipality of Šimanovci at a depth of $9.1 \mathrm{~m}$ to $9.3 \mathrm{~m}$. Based on the conducted experiments, it was determined that the soil is a highly plastic clay- $\mathrm{CH}$ clay with a yield limit $w p=56.5 \%$ and a plasticity index Ip $=37.1 \%$. The bulk density in the natural state with pores is $\rho=2.016 \mathrm{~g} / \mathrm{cm}^{3}$, while the dry bulk density is $\rho=1.631 \mathrm{~g} /$ $\mathrm{cm}^{3}$. The compressibility modulus for the stress level $100 \mathrm{kPa}-200 \mathrm{kPa}$ is $\mathrm{Mv}=10 \mathrm{MPa}$.

A drained direct shear test was performed. This test is standardly applied in practice and gives parameters expressed by effective stresses. For three levels of normal stresses $0 \mathrm{kPa}$, $100 \mathrm{kPa}$ and $200 \mathrm{kPa}$, a dependence is established between shear stress $\tau$ and shear displacements $\delta$ between the upper and lower part of the sample Figure 4 . The maximum values of shear stresses are plotted on the $(\sigma, \tau)$ diagram according to Figure 5 so that they define points on the stress envelope that is approximated by the linear dependenceCoulomb line $\tau=\sigma \operatorname{tg} \phi+\mathrm{c}$. Where, $\phi$ is the angle of internal friction, while $\mathrm{c}$ is the cohesion of the material. For the tested sample, the angle of internal friction is $\phi=20^{\circ}$, and the cohesion is $\mathrm{c}=7 \mathrm{kPa}$. 
8.

Савремена достигнућа у грађевинарству 22-23. април 2021. Суботица, СРБИЈА

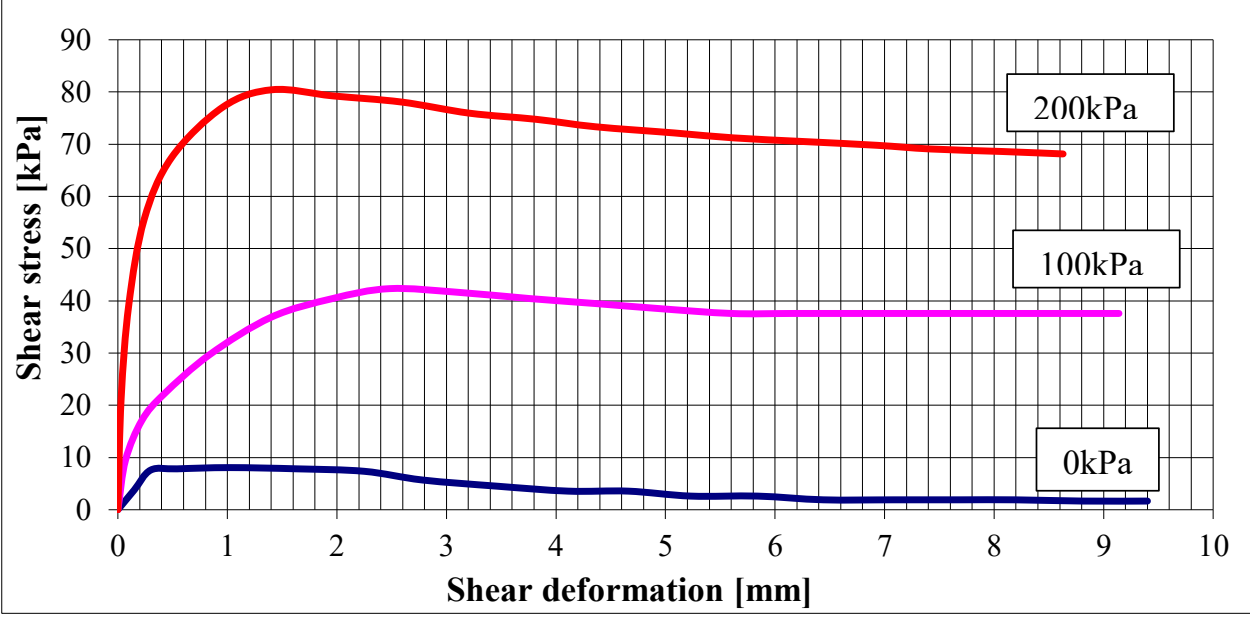

Figure 4. Results of direct shear test for three levels of stresses: $0 \mathrm{kPa}, 100 \mathrm{kPa}$ and 200 $\mathrm{kPa}$

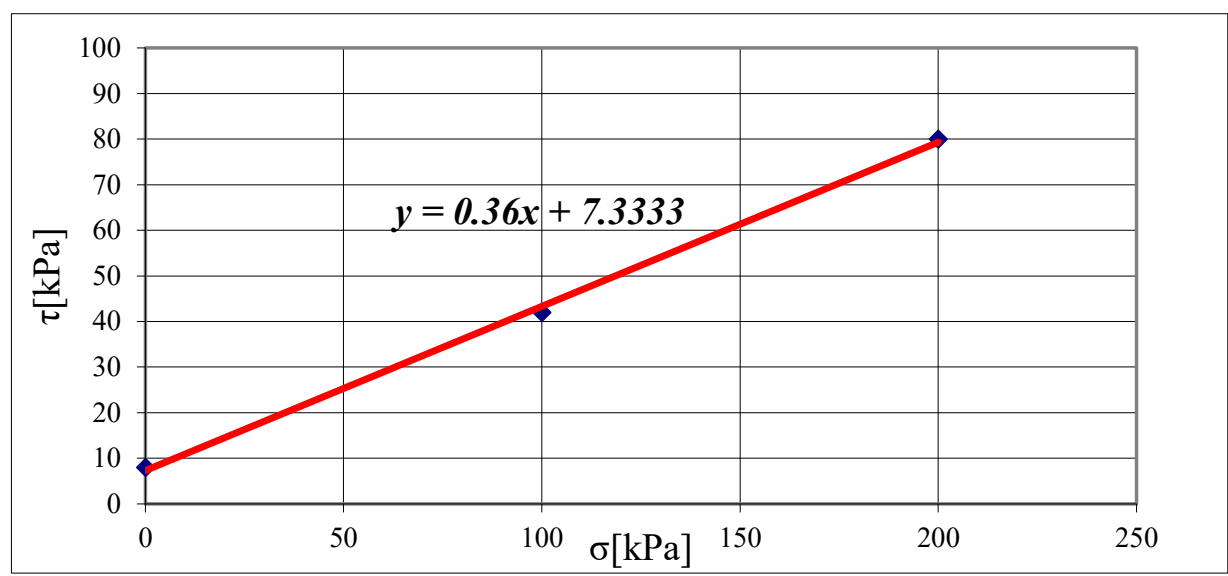

Figure 5. Coulomb linear line $\tau=\sigma \operatorname{tg} \phi+c$

Depending on the level of normal stresses, the soil can show a whole range of behaviors from brittle-plastic, through plastic, to tough fracture. As Preisach model finds application in elasto-plastic materials, clay in the experiment of direct shear expresses the properties of elasto-plasticity for the highest possible stress level. For these reasons, Preisach model will be applied for a stresses level of $200 \mathrm{kPa}$. Shear strain is obtained dividing the shear displacement by the height of the sample.

\section{ILLUSTRATIVE EXAMPLE}

To illustrate the application of the Preisach model the shear stress-slip monotonic curve is determined for material model of series connection of three unite element introduced in 


\section{$8^{\text {th }}$ inTERnATIONAL CONFERENCE}

Contemporary achievements in civil engineering 22-23. April 2021. Subotica, SERBIA

the previous subsection: two Hook's spring elements and one Saint-Venant's slip element. This model is supported by equation:

$$
\tau(t)=\frac{G}{2}\left(\int G_{\alpha-\alpha} \gamma(t) d \alpha-\frac{G-G_{h}}{2} x \frac{1}{Y_{\max }-Y_{\min }} \iint G_{\alpha, \beta} \gamma(t) d \alpha d \beta\right)
$$

In the calculation it is used $G$ and $G h$ as a slip module and hardening slip module and $Y \max$ and $Y$ min as upper yield and lower yield point. The curve is divided into two parts. The first part of curve is described by modules $G$ and $G h$, while the second part of curve for the calculation peak shear strength is described by modules $G h$ and $G a$ as shown in Figure 6 . For the calculation of the peak shear strength, the coordinate origin was moved to the stress level of $67.4 \mathrm{kPa}$, so the part of the curve to the peak shear strength was observed as a separate curve. All parametars for calculation are given in the Table 1 .

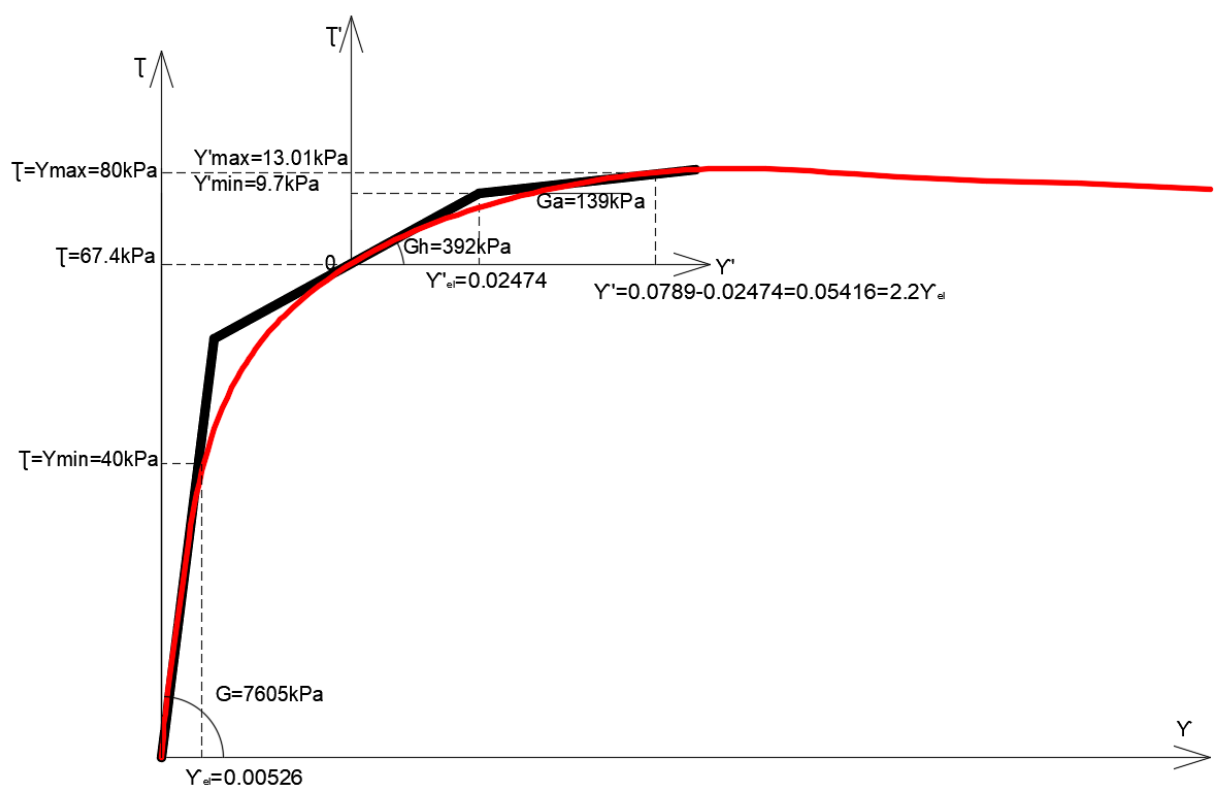

Figure 6. Parametars for caculation adopting from experimental curve

The calculation was performed in three steps. For $\gamma_{\mathrm{el}}=Y \mathrm{~min} / \mathrm{G}=0.00526$, the first step covers the slip area from 0 to $5 \gamma_{\mathrm{el}}$, the second area is from 0 to $10 \gamma_{\mathrm{el}}$, and the third area is from 0 to $15 \gamma_{\mathrm{el}}$. Figure 7 showes Preisach triangles for two divided parts of curve. 
8.

МЕЂУНАРОДНА КОНФЕРЕНЦИЈА

Савремена достигнућа у грађевинарству 22-23. април 2021. Суботица, СРБИЈА

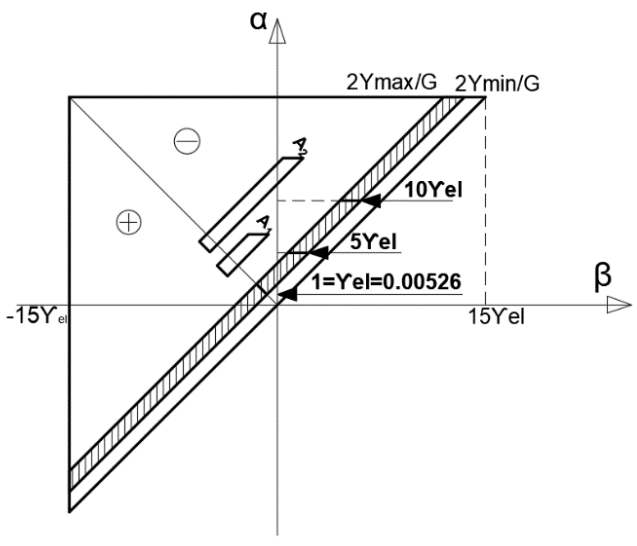

(a)

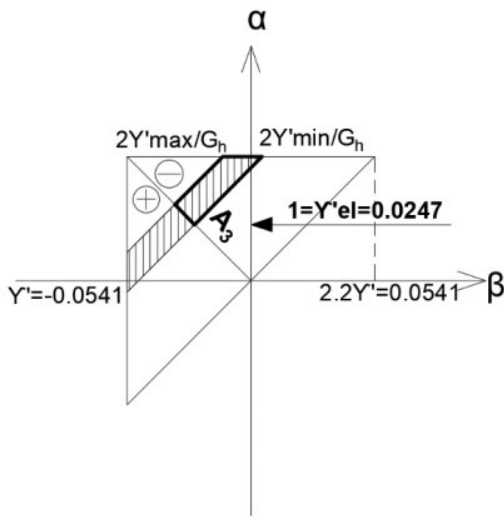

(b)

Figure 7. (a) Preisach triangle for the first and the second step for calculation (b) Preisach triangle for the third step for calculation

Table 1. Parametars for calculation

\begin{tabular}{|c|c|}
\hline $\begin{array}{c}\tau-\gamma \\
0<\gamma<10 \gamma_{\mathrm{el}}\end{array}$ & $\begin{array}{c}\tau^{\prime}-\gamma^{\prime} \\
10 \gamma_{\mathrm{el}}<\gamma<15 \gamma_{\mathrm{el}}\end{array}$ \\
\hline$Y_{\min }=40 \mathrm{kPa}$ & $\mathrm{Y}^{\prime}{ }_{\min }=9.7 \mathrm{kPa}$ \\
\hline $\mathrm{Y}_{\max }=\sigma \operatorname{tg} \phi+\mathrm{c}=80 \mathrm{kPa}$ & $\mathrm{Y}_{\max }^{\prime}=13.01 \mathrm{kPa}$ \\
\hline $\mathrm{G}=7605 \mathrm{kPa}$ & $\mathrm{G}_{\mathrm{h}}=392 \mathrm{kPa}$ \\
\hline $\mathrm{G}_{\mathrm{h}}=392 \mathrm{kPa}$ & $\mathrm{G}_{\mathrm{a}}=139 \mathrm{kPa}$ \\
\hline$\Upsilon_{\mathrm{el}}=0,00526$ & $\Upsilon^{\prime}{ }_{\mathrm{el}}=0,0275$ \\
\hline $2 \mathrm{Y}_{\max } / \mathrm{G}=0,021$ & $2 \mathrm{Y}^{\prime}{ }_{\max } / \mathrm{G}_{\mathrm{h}}=0.0495$ \\
\hline $2 \mathrm{Y}_{\min } / \mathrm{G}=0,0105$ & $2 \mathrm{Y}_{\mathrm{min}}^{\prime} / \mathrm{G}_{\mathrm{h}}=0.0664$ \\
\hline
\end{tabular}

The stress under limit $Y$ min is linear.

$$
\tau_{e l}=\frac{G}{2}\left[2 x \gamma_{e l}\right]=40 \mathrm{kPa}
$$

The first step of calculation $0<\gamma<5 \gamma_{\mathrm{el}}$ :

$$
\tau_{1}=\frac{G}{2}\left[2 x 5 \gamma_{e l}-\frac{G-G_{h}}{2} x \frac{1}{Y_{\max }-Y_{\min }} \times 2 \times A_{1}\right]=66.4 k P a
$$

The second step of calculation $0<\gamma<10 \gamma_{e l}$ :

$$
\tau_{2}=\frac{G}{2}\left[2 x 10 \gamma_{e l}-\frac{G-G_{h}}{2} x \frac{1}{Y_{\max }-Y_{\min }} \times 2 x A_{2}\right]=77.5 \mathrm{kPa}
$$


Contemporary achievements in civil engineering 22-23. April 2021. Subotica, SERBIA

The third step of calculation $0<\gamma<15 \gamma_{e l}$ :

$$
\begin{aligned}
\tau_{3}=\tau_{1}+\Delta \tau= & \tau_{1}+\frac{G_{h}}{2}\left[2 x 2.2 \gamma^{\prime}{ }_{e l}-\frac{G_{h}-G_{a}}{2} \times \frac{1}{Y_{\text {max }}^{\prime}-Y_{\text {min }}^{\prime}} \times 2 \times A_{3}\right] \\
= & 81 \mathrm{kPa}
\end{aligned}
$$

The Figure 8 shows comparasion of calculated values with experimental curve.

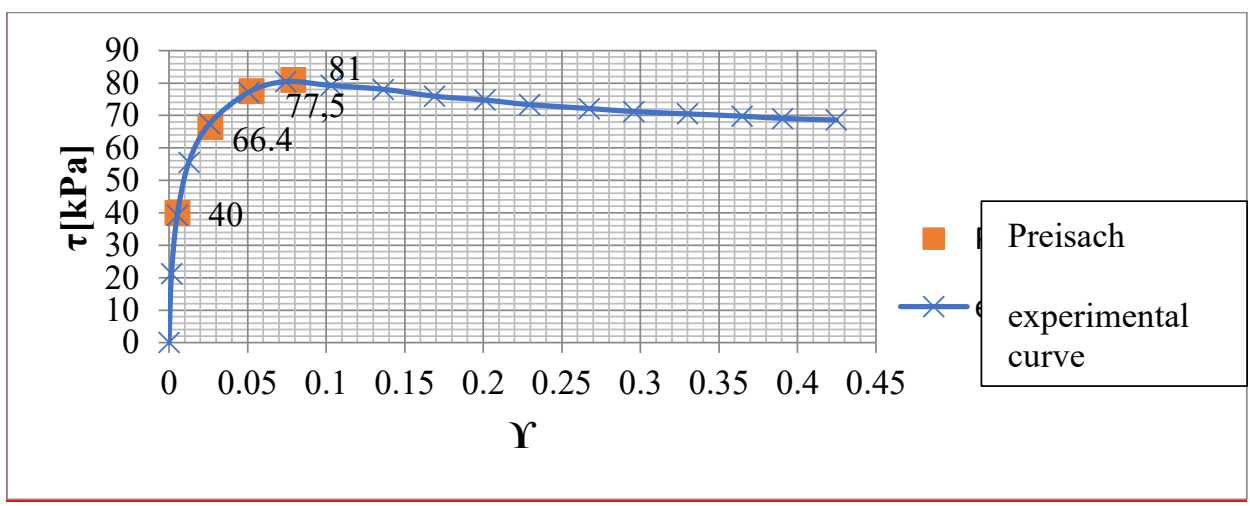

Figure 8. Comparation computed values with experimental curve

\section{CONCLUSION}

In present paper is considered the application of Preisach model for the calculation of soil shear resistance for a known shear deformation. Preisach model was primarily used to determine the response of elasto-plastic materials under cyclic loading. As Clay, due to the action of normal stress in the direct shear test, has the properties of elasto-plastic materials, the possibility of applying Preisach model for determining the curve of shear resistance-deformation was tested. It is difficult to perform a cyclic test of direct shear due to the limitations of the apparatus, also when shearing the soil, it is difficult to register the elactic deformation. The clay sample was exposed to direct shear for three stress levels. Preisach model was applied in the case of a normal stress of $200 \mathrm{kPa}$ to peak shear strength. The obtained values indicate that Preisach model can describe all phases of shear behavior of clay: elastic phase, hardening and the peak strength as well.

\section{REFERENCES}

[1] Preisach, F. "About the magnetic aftereffect (Über die magnetische Nachwirkung)", Zeitschrift für Physik, 94, pp. 277-302, (1935). (inGerman) https://doi.org/10.1007/BF01349418 
8.

Савремена достигнућа у грађевинарству 22-23. април 2021. Суботица, СРБИЈА

[2] Lubarda, A. V., Sumarac, D., Krajcinovic, D. "Hysteretic Response of Ductile Materials Subjected to Cyclic Loads", In: Ju, J. W. (ed.) Recent Advances in Damage Mechanics and Plasticity, 123, (1992), pp. 145-157.

[3] Lubarda, A. V., Sumarac, D., Krajcinovic, D. "Preisach Model and Hysteretic Behavior of Ductile Materials", European Journal of Mechanics- A/Solids, 12(4), pp. 445-470, (1993).

[4] Dragoslav Šumarac, Zoran Perović, "Cyclic plasticity of trusses", Archive of Applied Mechanics: Volume 85, Issue 9, Page 1513-1526, (2015).

[5] Petar Knežević, Dragoslav Šumarac, Zoran Perović, Ćemal Dolićanin, Zijah Burzić, "A Preisach Model for Monotonic Tension Response of Structural Mild Steel with Damage", (2019)

[6] Mayergoyz, I. D.: Mathematical Models of Hysteresis, Springer-Verlag, New York (1991).

[7] Sumarac, D., Stosic, S.: "Preisach Model for the Cyclic Bending of Elastoplastic Beams", Europ. Journal of Mechanics, A/Solids, 15, $\mathrm{n}^{0}$ 1, 155-172, (1996).

[8] Šumarac, D and Petrašković, Z: "Hysteretic behavior of rectangular tube (box) sections based on Preisach model“, Archive of Applied Mechanics: Volume 82, Issue 10, Page 1663-1673, (2012). 